\title{
Pengaruh Pemberian Kode Warna Wilayah Pada Folder Terhadap Ketepatan Penyimpanan Berkas Rekam Medis Di Puskesmas Wadaslintang 1
}

\author{
Deni Gunawan \\ Program Studi D3 Teknik Elektro dan Rekam Medis Kesehatan, Politeknik Dharma Patria
} Kebumen

\begin{tabular}{l}
\hline \hline Article Info \\
\hline Article history: \\
Received June 28, 2021 \\
Revised July 15, 2021 \\
Accepted July 19, 2021 \\
\hline
\end{tabular}

Keywords:

Regional Color Code in Medical Record File Folder Medical Record File Storage

\begin{abstract}
A Medical records are files containing notes and documents regarding the patient's identity, examination, treatment, actions and other services that have been provided to patients. So that a medical file is strictly protected so that it is not damaged or lost. Based on observations, it was found that there were several files of medical records that were interchanged or not in the normal filling rack. Medical record files can be exchanged due to the large number of regional shelf columns so that alternatives and innovations are needed to increase the accuracy of returning and retrieving medical record files correctly. Troubleshooting efforts are being made, namely by providing a regional color code in the medical record file folder so that errors in taking and returning medical record files can be minimized. Based on the results of observations made by the author, it was found that there was an effect before and after color coding the region in the medical record file folder.
\end{abstract}

\section{Corresponding Author:}

Deni Gunawan,

Program Studi D3 Teknik Elektro dan Rekam Medis Kesehatan,

Politeknik Dharma Patria Kebumen,

Jl. Letjend Suprapto No. 73 Kebumen Jawa Tengah.

Email: denigunawan3270@gmail.com

\section{PENDAHULUAN}

Puskesmas merupakan kesatuan organisasi fungsional yang menyelenggarakan upaya kesehatan yang bersifat menyeluruh, terpadu, merata dapat diterima dan terjangkau oleh masyarakat dengan peran serta aktif masyarakat dan menggunakan hasil pengembangan ilmu pengetahuan dan teknologi tepat guna, dengan biaya yang dapat dipikul oleh pemerintah dan masyarakat luas guna mencapai derajat kesehatan yang optimal [1].

Dalam mencapai tujuan tentu para tenaga medis harus melakukan tugasnya sesuai dengan porsi yang telah ditentukan, salah satunya adalah perekam medis yang harus mampu mengelola data rekam medis pasien sehingga kegiatan pelayanan kesehatan akan lebih lancar dan tidak terjadi kekeliruan terutama dalam penyimpanan berkas rekam medis [2].

Kegiatan perekam medis dalam suatu instansi pelayanan kesehatan sangatlah penting, dikerenakan rekam medis memiliki beberapa fungsi, diantaranya adalah dasar 
pemeliharaan kesehatan dan pengobatan pasien; bahan pembuktian dalam perkara hukum; bahan untuk keperluan penelitian dan pendidikan; dasar pembayaran biaya pelayanan kesehatan; dan bahan untuk menyiapkan statistik kesehatan. Oleh karena itu dalam sistem peyimpanan berkas rekam medis harus dilakukan secara benar sesuai peraturan yang ada sehingga perekam medis akan mudah untuk menemukan serta mengembalikan berkas rekam medis ketika dibutuhkan [3].

Untuk mempermudah jalannya kegiatan perekam medis di Puskesmas Wadaslintang 1, maka perekam medis melakukan beberapa metode diantaranya memberikan kode nomor wilayah pada setiap berkas rekam medis sehingga berkas rekam medis akan mudah untuk ditemukan ketika akan dibutuhkan, namun demikian masih saja terdapat permasalahan yang terjadi ketika kegiatan perekam medis berlangsung, salah satunya kekeliruan penyimpanan berkas rekam medis pada rak sehingga akan membutuhkan waktu yang lama ketika berkas rekam medis akan dicari. Oleh kerena itu maka perekam medis perlu membuat inovasi supaya dapat meminimalisir terjadinya permasalahan.

Para ahli psikologi mengatakan bahwa otak manusia akan mudah mengingat suatu hal pada objek-objek yang lebih menonjol atau unik, hal tersebut biasa disebut sebagai efek isolasi, hal tersebut juga biasa digunakan oleh para pembisinis dalam memperkenalkan brandnya atau yang disebut sebagai psikologi warna pada branding, yaitu bagaimana sebuah warna dari brand dapat memengaruhi kesadaran, pengalaman, hingga keputusan konsumen dalam memilih brand anda, mengingat akan hal tersebut maka pemberian kode warna pada wilyah diharapkan mampu untuk memperkecil terjadinya suatu permasalahan baik dalam pengambilan maupun pengembalian berkas rekam medis pasien. Namun penerapan kode warna wilayah ini lebih efektif diterapkan pada folder berkas rekam medis dikarena jika kode warna ini diterapkan pada folder maka perekam medis akan mudah mengenali lokasi penyimpanan berkas rekam medisnya mengingat jumlah folder yang telah berjejer disetiap kolom rak penyimpanan dari pada memberikan kode warna pada bagian rak penyimpanannya saja [4].

\section{METODE PENELITIAN}

Jenis penelitian yang dilakukan adalah penelitian kuantitatif yaitu menginvestigasi permasalahan ketidaktepatan penyimpanan berkas rekam medis pada rak dengan mengumpulkan beberapa data yang dapat diukur dengan menggunakan metode survei dan eksperimen [5].

Eksperimen yang dilakukan adalah memberikan kode warna wilayah pada folder berkas rekam medis di Puskesmas Wadaslintang 1 [4], kemudian membandingkan apakah ada perbedaan sebelum dan sesudah eksperimen tersebut dilakukan. Lokasi penelitian ini berada di Puskesmas Wadaslintang 1 dengan lama penelitian 1 bulan terhitung dari tanggal 15 Desember 2020 hingga 15 Januari 2021.

Sistem pengambilan sampel yang digunakan adalah Probality Sampling dengan pendekatan Cluster Sampling yaitu berkas rekam medis dikelompokan berdasarkan kode wilayah masing-masing kemudian peneliti menentukan 5 wilayah sampel yang dianggap telah mewakilidari 19 wilayah yang ada [6]. Wilayah yang terpilih menjadi sampel adalah: 
Tabel 1. Sampel Berkas Rekam Medis Berdasarkan Wilayah

\begin{tabular}{ccl}
\hline No & \multicolumn{1}{c}{ Wilayah } & \multicolumn{1}{c}{ Alasan } \\
\hline 1. & Wadaslintang & $\begin{array}{l}\text { Memiliki jumlah kepala keluarga terbanyak yang telah } \\
\text { memiliki berkas rekam medis, yaitu sebanyak 1937 KK. }\end{array}$ \\
\hline 2. & Kaligowong & $\begin{array}{l}\text { Memiliki kode wilayah 001 yang dikhawatirkan bisa } \\
\text { tertukar dengan kode 010 yaitu daerah Lancar. }\end{array}$ \\
\hline 3. & Lancar & $\begin{array}{l}\text { Memiliki kode wilayah 010 yang dikhawatirkan bisa } \\
\text { tertukar dengan kode 001 yaitu daerah Kaligowong. }\end{array}$ \\
\hline 4. & Sumbersari & $\begin{array}{l}\text { Memiliki jumlah kepala keluarga paling sedikit yang telah } \\
\text { memiliki berkas rekam medis, yaitu sebanyak 91 KK. }\end{array}$ \\
\hline 5. & Plunjaran & Mengambil data Median dari 19 wilayah yang ada. \\
\hline \multicolumn{2}{c}{ Berikut kami paparkan populasi atau daftar wilayah yang terdaftar di Puskesmas } \\
Wadaslintang 1.
\end{tabular}

Tabel 2. Daftar Wilayah yang Terdaftar di Puskesmas Wadaslintang 1

\begin{tabular}{ccc}
\hline Kode & Nama Wiayah & Jumlah KK \\
\hline 001 & Kaligowong & 631 \\
\hline 002 & Sumbersari & 91 \\
\hline 003 & Sumberjo & 332 \\
\hline 004 & Erorejo & 531 \\
\hline 005 & Karanganyar & 932 \\
\hline 006 & Panerusan & 1221 \\
\hline 007 & Wadaslintang & 1937 \\
\hline 008 & Plunjaran & 782 \\
\hline 009 & Kumejing & 615 \\
\hline 010 & Lancar & 1237 \\
\hline 011 & Somogede & 994 \\
\hline 012 & Trimulyo & 1773 \\
\hline 013 & Tirip & 1766 \\
\hline 014 & Besuki & 874 \\
\hline 015 & Gumelar & 259 \\
\hline 016 & Ngalian & 942 \\
\hline 017 & Kalidadap & 216 \\
\hline 018 & Luar Kecamatan & 262 \\
\hline 019 & Luar Kabupaten & 248 \\
\hline
\end{tabular}

\section{HASIL DAN PEMBAHASAN}

\subsection{Hasil}

Setelah dilakukan survei sesuai dengan sampel yang digunakan ternyata terdapat beberapa berkas rekam medis yang salah penempatan pada rak penyimpanan, yaitu seperti tabel berikut ini.

Tabel 3. Hasil Survei

\begin{tabular}{clcc}
\hline No. & Wilayah & Jumlah Total RM & Jumlah Kesalahan RM \\
\hline 1. & Kaligowong & 631 & 5 \\
\hline 2. & Lancar & 1237 & 5 \\
\hline 3. & Wadaslintang & 1937 & 7 \\
\hline 4. & Sumbersari & 91 & 0 \\
\hline 5 & Plunjaran & 782 & 0 \\
\hline
\end{tabular}

Dari hasil survei tersebut diketahui bahwa ada beberapa wilayah yang salah penempatan dalam penyimpanan berkas rekam medis, diantaranya adalah wilayah 
Kaligowong, Lancar dan Wadaslintang. Pada wilayah Kaligowong ternyata terdapat 5 berkas rekam medis yang tertukar tempat dengan wilayah Lancar, hal ini disebabkan karena kode berkas rekam medis yang hampir sama dimana untuk wilayah Kaligowong memiliki kode wilayah 001 sedangkan wilayah Lancar 010. Selain dua wilayah tersebut pada wilayah Wadaslintang juga terdapat kesalahan penempatan berkas rekam medis, hal ini dikarenakan terlalu banyak berkas rekam medis pada wilayah Wadaslintang yaitu sekitar 1937 KK yang terdaftar.

Setelah mendapatkan hasil dari survei yang telah dilakukan, maka dilakukan suatu percobaan yang telah dipelajari berdasarkan teori psikologi mengenai efekisolasi [4] selama 2 minggu setelah dilakukan survei pertama, dan menghasilkan hasil seperti tabel berikut ini.

Tabel 4. Hasil Percobaan

\begin{tabular}{clcc}
\hline No & Wilayah & Jumlah Total RM & Jumlah Kesalahan RM \\
\hline 1. & Kaligowong & 631 & 0 \\
\hline 2. & Lancar & 1237 & 0 \\
\hline 3. & Wadaslintang & 1937 & 0 \\
\hline 4. & Sumbersari & 91 & 0 \\
\hline 5. & Plunjaran & 782 & 0
\end{tabular}

Dari hasil tersebut maka dapat kita amati bahwa ada perubahan data jumlah kesalahan dari sebelum dan sesudah menerapkan pemberian kode warna wilayah pada folder berkas rekam medis di Puskesmas Wadaslintang 1.

Pada wilayah Kaligowong yang awalnya terdapat 5 berkas rekam medis yang mengalami kesalahan penempatan berkas setelah menerapkan kode warna wilayah menjadi tidak ada kesalahan penempatan lagi, hal tersebut juga dialami pada berkas rekam medis yang berada pada wilayah Lancar dan Wadaslintang.

Berikut disajikan grafik perbandingan persentase ketepatan penempatan penyimpanan berkas rekam medis sesudah dan sebelum menerapkan kode warna wilayah pada folder berkas rekam medis di Puskesmas Wadaslintang 1.

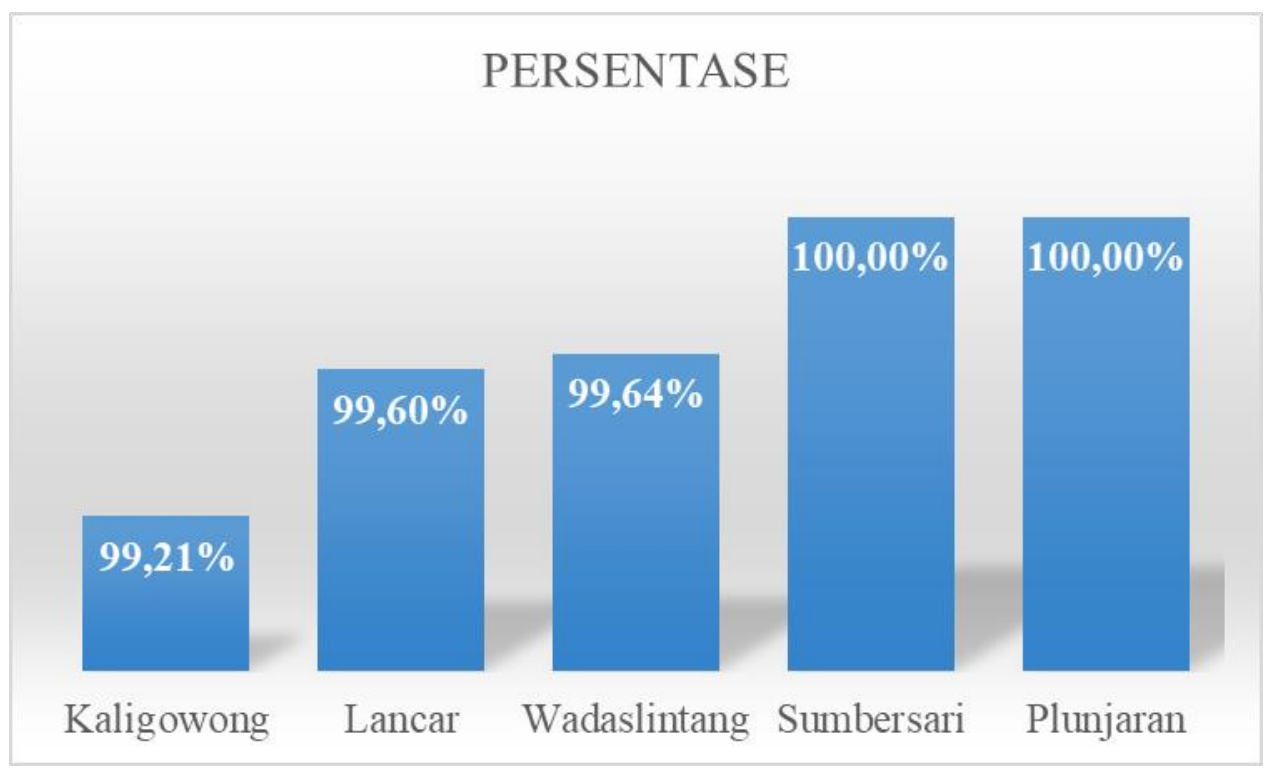

\section{Gambar 1. Persentase Ketepatan Penyimpanan Berkas Rekam Medis Sebelum Menerapkan Kode Warna Wilayah Pada Folder Berkas Rekam Medis di Puskesmas Wadaslintang 1}

Dari grafik 1 tersebut menunjukan bahwa tingkat ketepatan penyimpanan berkas rekam medis pada wilayah kaligowong sebesar $99,21 \%$ yang artinya terdapat $0,79 \%$ 
ketidaktepatan dalam penyimpanan berkas rekam medis dalam wilayah tersebut. Pada wilayah Lancar menunjukan 99,60\% ketapatan penyimpanan berkas rekam medis dan $0,40 \%$ ketidaktepatan penyimpanan berkas rekam medis, pada wilayah Wadaslintang menunjukan 99,64\% ketepatan penyimpanan berkas rekam medis dan 0,36\% ketidaktepatan dalam penyimpanan berkas rekam medis sedangkan pada wilayah Sumbersari dan Plunjaran menunjukan $100 \%$ tepat dalam penyimpanan berkas rekam medis.

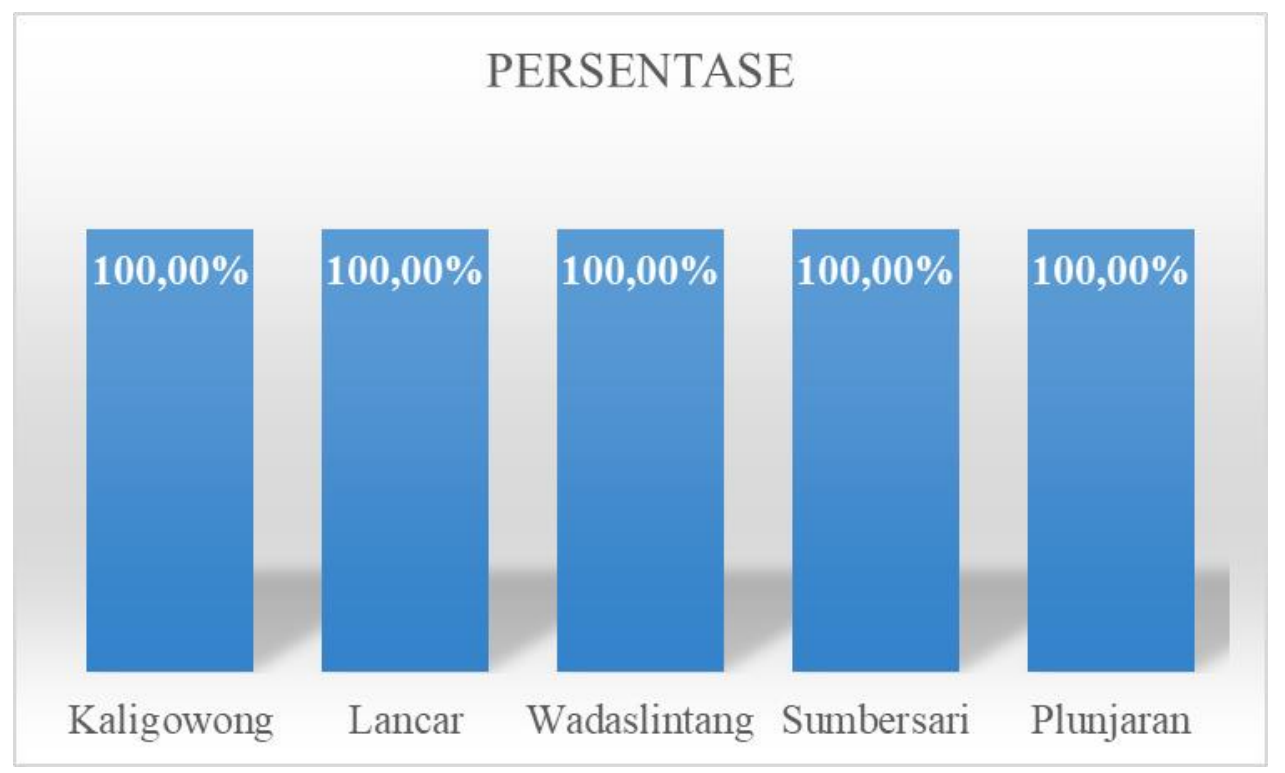

\section{Gambar 2. Persentase Ketepatan Penyimpanan Berkas Rekam Medis Setelah Menerapkan Kode Warna Wilayah Pada Folder Berkas Rekam Medis di Puskesmas Wadaslintang 1}

Dari gambar 2 tersebut menunjukan bahwa setelah menerapkan kode warna wilayah pada folder berkas rekam medis maka tingkat ketepatan penyimpanan berkas rekam medis menunjukan persentase $100 \%$ yang artinya tidak ada kesalahan atau ketidaktepatan dalam penyimpanan berkas rekam medis di Puskesmas Wadaslintang 1.

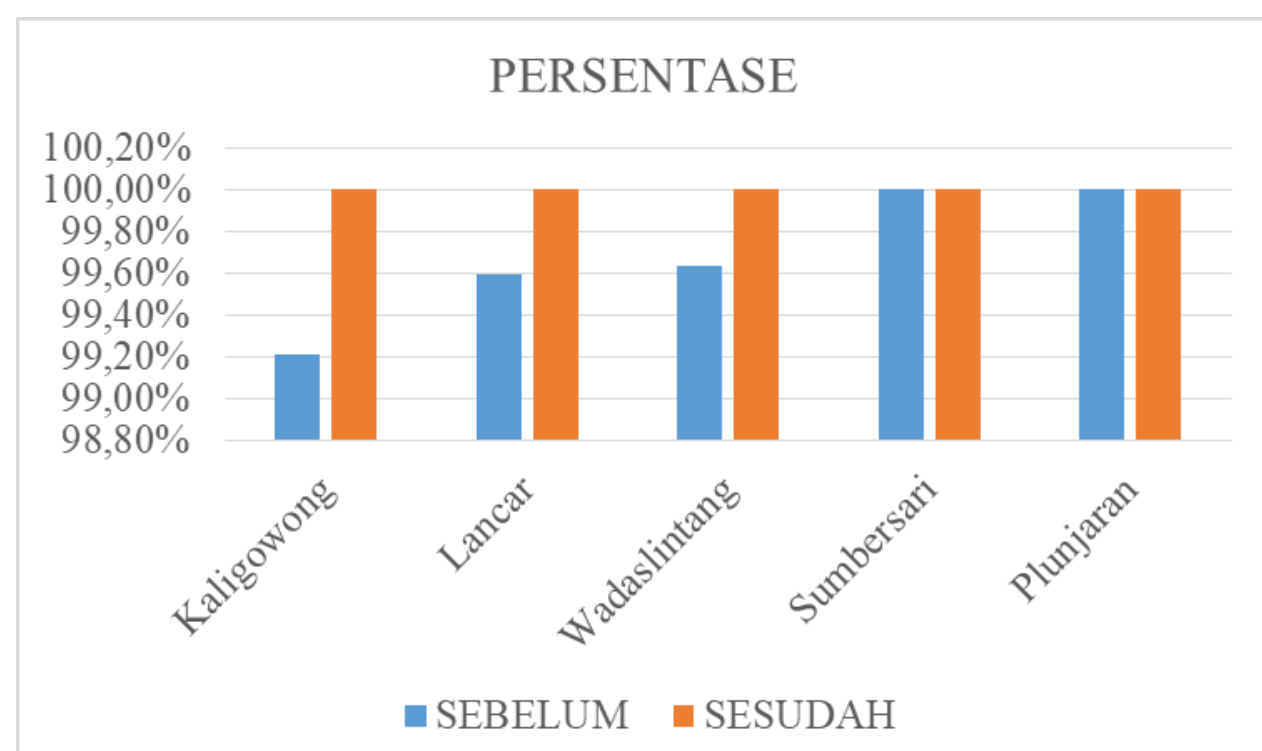

Gambar 3. Perbandingan Persentase Ketepatan Penyimpanan Berkas Rekam Medis Sebelum dan Sesudah Menerapkan Kode Warna Wilayah Pada Folder Berkas Rekam Medis di Puskesmas Wadaslintang 1 
Dari gambar 3 tersebut menunjukan adanya perbedaan persentase dalam ketepatan penyimpanan berkas rekam medis sebelum dan sesudah menerapkan kode warna wilayah pada folder berkas rekam medis di Puskesmas Wadaslintang 1, yaitu pada wilayah Kaligowong sebelumnya memiliki persentase ketepatan sebesar 99,21\% dan setelah menerapkan kode warna wilayah menjadi $100 \%$, begitu juga dengan wilayah-wilayah lainnya, yaitu wilayah lancar sebelumnya $99,60 \%$ dan setelah menerapkan kode warna wilayah kini menjadi $100 \%$ dan yang terakhir adalah wilayah Wadaslintang sebelumnya $99,64 \%$ sekarang menjadi $100 \%$.

\subsection{Pembahasan}

Dari data-data yang telah diperoleh maka ditemukan beberapa fakta diantaranya adalah adanya perbedaan persentase kelengkapan penyimpanan berkas rekam medis sebelum dan setelah diterapkan kode warna wilayah pada folder berkas rekam medis.

Sebelum diterapkan kode warna wilayah pada folder berkas rekam medis wilayah kaligowong menunjukan 99,21\% ketepatan dan setelah diterapkan kode warna wilayah menjadi $100 \%$ sehingga ada kenaikan sebesar $0,79 \%$. Pada wilayah Lancar yang awalnya $99,60 \%$ kini menjadi $100 \%$ yang berarti ada kenaikan sebesar $0,40 \%$ dan pada wilayah Wadaslintang yang semula 99,64\% mengalamikenaikan $0,36 \%$.

Dari hasil tersebut menunjukan kebenaran akan teori efek isolasi pada warna [4], dimana setiap cover folder diberikan tanda berupa label dengan warna yang berbeda setiap wilayahnya, diantaranya untuk wilayah Kaligowong diberi warna merah, Lancar diberi warna kuning, Wadaslintang diberi warna hijau, Sumbersari diberi warna biru dan Plunjaran diberi warna ungu. Dengan adanya pembeda warna tersebut ditambah kode angka yang telah tertera disetiap cover folder maka dapat meminimalisir terjadinya kesalahan dan menambah tingkat kefokusan perekam medis dalam penyimpanan berkas sesuai dengan tempat yang telah ditentukan.

\section{Kesimpulan}

Pemberian kode warna wilayah pada folder berkas rekam medis di Puskesmas Wadaslintang 1 sangat berpengaruh dalam ketepatan penyimpanan berkas rekam medis, terbukti dengan angka persentase yang mengalami kenaikan setelah diterapkannya kode warna wilayah pada berkas rekam medis di Puskesmas Wadaslintang 1.

\section{REFERENCES}

[1] R. Maliya, "Sistem Informasi Geografis Puskesmas Di Bandar Lampung," $J$. Cendikia, vol. 19, no. 1, pp. 419-423, 2020.

[2] S. Z. Fenia and Y. Candra, "Ketetapan Jumlah Petugas Filing Dengan Ketepatan Penyimpanan Rekam Medis Di Rumah Sakit X Padang," J. Ekon. dan Bisnis Dharma Andalas, vol. 21, no. 2, pp. 231-239, 2019.

[3] A. Deharja, Buku Ajar Praktik Klinis Rekam Medis (Pengantar Awal Turun Lapang). Pelita Medika, 2021.

[4] H. Wahyudi, "Optimalisasi Daya Kerja Otak Melalui Pemanfaatan Stimulan Eksternal," J. Pembelajaran Fis., vol. 5, no. 4, pp. 384-391, 2017.

[5] G. R. Somantri, "Memahami metode kualitatif," Makara Hum. Behav. Stud. Asia, vol. 9, no. 2, pp. 57-65, 2005.

[6] N. Nurdiani, "Teknik sampling snowball dalam penelitian lapangan," ComTech Comput. Math. Eng. Appl., vol. 5, no. 2, pp. 1110-1118, 2014. 


\section{BIOGRAPHIES OF AUTHORS}

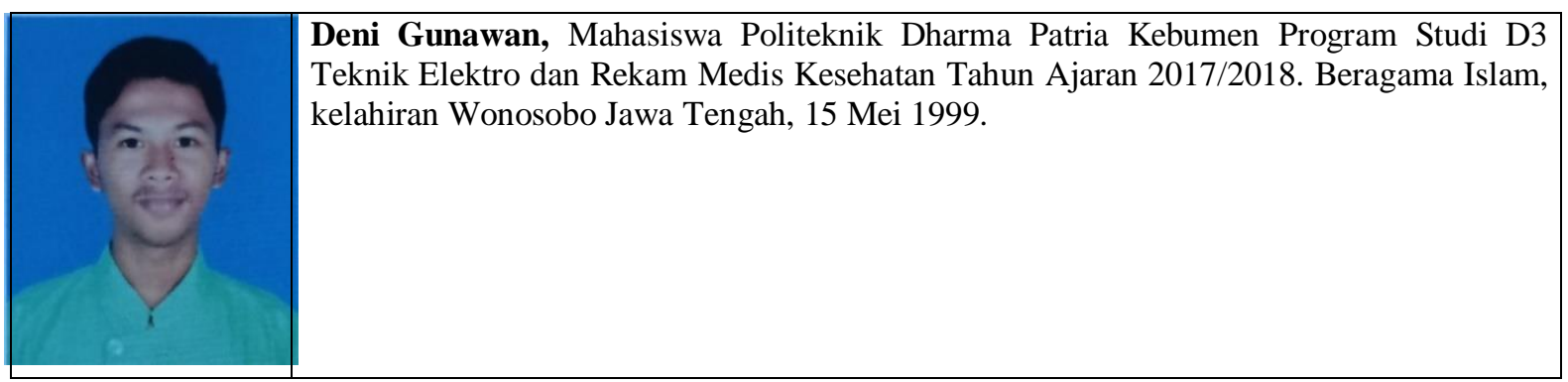

